\title{
PIK3R2 wt Allele
}

National Cancer Institute

\section{Source}

National Cancer Institute. PIK3R2 wt Allele. NCI Thesaurus. Code C101284.

Human PIK3R2 wild-type allele is located within 19q13.2-q13.4 and is approximately $17 \mathrm{~kb}$ in length. This allele, which encodes phosphatidylinositol 3-kinase regulatory subunit beta protein, plays a role in the modulation of tyrosine phosphorylation. 